\title{
Impacts of insect consumption on human health
}

\author{
V.J. Stull \\ University of Wisconsin-Madison, Global Health Institute, 1050 Medical Sciences Center, 1300 University Avenue, Madison, \\ WI 53706, USA; vstull@wisc.edu
}

Received: 5 September 2020 / Accepted: 7 December 2020

(c) 2021 Wageningen Academic Publishers

OPEN ACCESS C(1) R(2) REVIEW ARTICLE

\begin{abstract}
Edible insects represent an understudied food resource that may promote human health. They characteristically contain ample protein, healthy fatty acids, minerals, and vitamins, and have been touted for their environmental benefits given their efficient resource use. While numerous in vitro, animal, and nutrient quantification studies have elucidated a framework of potential health impacts of entomophagy, few have measured direct health outcomes. This review investigates and summarises existing evidence on health impacts derived exclusively from human interventions. A systematic literature search was conducted in three databases: SCOPUS, Web of Science, and PubMed. Out of 1,691 initial results, only nine studies met the inclusion criteria. In these limited studies, insects were shown to have potential to: (1) promote growth and influence iron status when added to complementary foods; (2) modulate gut microbiota with some prebiotic effects; and (3) provide amino acids similar to soya protein. One study also provided isolated evidence that an insect-herb mixture could possibly reduce symptoms of chronic obstructive pulmonary disease when added to routine treatment. Importantly, results reveal a significant lack of human subjects research directly measuring health outcomes from insect consumption. Findings from the included studies indicate that insects are generally safe and offer both beneficial and neutral outcomes compared to other foods. These discoveries, in tandem with extensive evidence from non-human studies, support claims that insect consumption could further enhance health by addressing micronutrient deficiencies or promoting gut health. There are also other plausible health promoting properties of insects that could help ameliorate complications with hypertension and other non-communicable disease. More rigorous and better controlled human intervention trials are fundamental to confirm health benefits and better assess risks associated with entomophagy, while also addressing unanswered questions regarding nutrient bioavailability, the fate of dietary chitin, and in vivo activity of bioactive peptides.
\end{abstract}

Keywords: entomophagy, edible insects, health impacts, nutrition, clinical trial, dietary intervention

\section{Introduction}

The global food system faces an unprecedented array of challenges, which will have ramifications for human health. Farmers and communities are pressured by climate change, inequitable trade, food waste, supply chain disruptions, and the need to support a growing population while demand for resource-intensive animal products rises (Ranganathan et al., 2016). Animals are an important protein source for many, but livestock production, particularly beef, is one of the largest contributors of greenhouse gas emissions and has also been blamed for other harms to the environment (Poore and Nemecek, 2018). Consequently, novel and sustainable protein production will be required in the decades to come.

Global food security has improved in recent decades, but advances have not been uniform and challenges remain. An estimated 690 million people faced chronic undernourishment in 2019 (FAO et al., 2020), despite adequate global food supplies. Malnutrition kills more people than AIDS, malaria, and tuberculosis combined (WFP, 2015). Undernutrition weakens the immune system and is responsible for more than $45 \%$ ( $>3$ million) of annual deaths among children under five in developing countries (Black et al., 2013). Severe protein energy malnutrition 
(PEM) can manifest in muscle atrophy, wasting syndrome, or an increased risk of tuberculosis and gastroenteritis. Anaemia resulting from iron or vitamin $\mathrm{B}_{12}$ deficiency is a major global health risk (Ritchie and Roser, 2017), and low haemoglobin during pregnancy contributes to the between 2.5 and 3.4 million maternal and neonatal deaths that occur each year (Liu et al., 2012; Stevens et al., 2013). In other contexts, overweight and obesity stress healthcare systems as about 650 million people experienced obesity in 2016 (WHO, 2020). The double burden of simultaneous under- and overnutrition also challenges many governments. Increasing insect consumption could help address nutrition-related health problems by safely supplying micro and macronutrients.

While largely overlooked in Western cuisine today, insects are frequently included in traditional dishes across continents. Entomophagy - the practice of eating insects is not a new phenomenon. Many species have served as an important part of the diet throughout history (Bodenheimer, 1951; DeFoliart, 1995). The practice is highlighted in ancient religious texts, including the Bible (see Leviticus 11:22), and more than 2,100 known edible insects have been identified to-date (Jongema, 2017).

A recent research boom has begun to unpack the many prospects of insects as both food and feed, where previously a paucity of studies existed (Baiano, 2020). The nutritional value of insects has been widely explored, though these data are still sparse relative to the surfeit of edible species and myriad variables impacting nutrient composition. Recent anthropological research has explored insects in human evolution (Lesnik, 2018) and entomologists are even unpacking edible insect genomes (Ylla et al., 2020). Other studies have focused on purported environmental benefits of insect agriculture. There is evidence they require less water, land, and feed than conventional livestock while emitting fewer greenhouse gases (Oonincx et al., 2010; Van Huis et al., 2013).

Generalising nutrient composition across species and growth parameters is difficult, but insects characteristically have nutrient-dense profiles akin to meat - rich in protein and fat, low in carbohydrates. Many species contain ample energy, protein, and healthy fatty acids, while also providing essential minerals, and even some vitamins (Rumpold and Schlüter, 2013). Insects are considered a good source of protein with crude levels comparable to and sometimes even higher than other conventional meat sources (Belluco et al., 2013; Finke, 2002; Melo et al., 2011). The quality of insect protein is said to be high; it is broadly considered bioavailable and relatively digestible (Belluco et al., 2013; Finke, 2015; Verkerk et al., 2007). Insects also provide essential amino acids for human nutrition (Bukkens, 2005; Collavo et al., 2005; Rumpold and Schlüter, 2013), which are particularly valuable in contexts where malnutrition is problematic. Edible insects are also often a good source of fat with numerous species providing healthy polyunsaturated fatty acids (Womeni et al., 2009) including omega-3s (Paul et al., 2017; Wathne et al., 2018). There is some evidence that modifying insect diets can improve fat composition and ratios (Oonincx et al., 2019). Notably, data related to the nutrient content of insects are often low-quality and limited to within-species variation in proportions of microand macronutrients (Payne et al., 2016).

Insects offer myriad potential health benefits that have yet to be fully explored, including those stemming from bioactive compounds with antioxidant or other properties and dietary fibre (Roos and Van Huis, 2017). Insect consumption is not without risks, however. Food safety considerations are important when consuming insects, as they are also potential sources of allergenic, toxic, or antinutrient substances (Rumpold and Schlüter, 2013).

Numerous studies have investigated potential health impacts of insect consumption - from nutritional analyses (Belluco et al., 2013; Rumpold and Schlüter, 2013; Womeni et al., 2009) and hypotheses as to impacts on deficient populations (Nadeau et al., 2015), to laboratory studies where insect components are tested on cell cultures in vitro (Latunde-Dada et al., 2016) or fed to animals (Bergmans et al., 2020). These studies provide a foundational understanding of how entomophagy could influence human health. However, they do not demonstrate causality, nor do they fully explore other key variables driving health outcomes from entomophagy, such as nutritional/immune status of the consumer, presence of antinutrients in insects, processing methods, nutrient bioavailability, allergens, or contaminants.

It remains relatively unclear if and how eating insects improves human health. Are insects unique when compared to other animal foods? Do they contain nutrients or properties that correlate with benefits or detriments to human health? This purpose of this review is to summarise existing evidence from human intervention studies that measure human health outcomes resulting from entomophagy.

\section{Methods}

\section{Search strategy}

To define the scope of this broad topic and investigate health impacts of insect consumption, a systematic review was conducted. The search strategy was developed in consultation with a health sciences academic librarian. Three primary databases were searched, including Web of Science, PubMed, and SCOPUS. The final searches were completed on July 10, 2020. To standardise, two 'AND' categories were applied to basic title, abstract, and 
keyword searches in all three databases. An example of a primary search syntax is included in Appendix A. No limits for language, year of publication, author affiliation, or geographic region were applied.

Following the database searches, a secondary search using Google Scholar was conducted to find articles cited in found manuscripts with relevant titles not identified by preliminary searches. Additionally, a repeat of the key search strategy was implemented in Google Scholar with one modification. The names of specific edible insect types (e.g. 'cricket,' 'caterpillar,' 'termite,' 'beetle, 'weevil', 'stinkbug,' 'grasshopper,' 'ant,' 'wasp,' 'bee,' 'dragonfly') were added to the first search category to identify articles lacking generic terms such as 'edible insects' or 'entomophagy' in the title or abstract.

\section{Inclusion and exclusion criteria}

Following the searches, duplicate results were removed. Next, all titles, abstracts, and keywords were examined for eligibility via the primary inclusion and exclusion criteria. For studies that appeared to meet the inclusion criteria or where no determination could be made based on abstract and title alone, full text articles were reviewed.

All types of peer-reviewed clinical trials, dietary interventions, and acceptability studies whereby human subjects consumed edible insects and health outcomes were measured were included. Studies using insects in various states (raw, whole, processed, modified, added to other foods, or deconstructed into component parts) with or without a control group were included. Studies on insect products (e.g. silk proteins, honey) were excluded. For the purposes of this review, the category 'edible insects' included non-insects arthropods, such as spiders, that are widely grouped with insects in this field.
Search results that were not peer reviewed, such as books and reports, were excluded. Additionally, surveys, animal feeding trials, systematic and narrative reviews, commentaries, consumer taste trials, basic nutrient analyses, and studies not involving direct and monitored human consumption of insects with measured health impacts were excluded. Retrospective case reports outlining health outcomes associated with self-reported insect consumption were excluded.

\section{Results}

A total of 2,668 citations were collected in the initial searches of Web of Science, SCOPUS, and PubMed. Titles were screened, and a secondary search using Google Scholar for references in key manuscripts and insect-specific studies identified 15 additional papers, making the total 2,681 . Systematic deduplication yielded 1,691 citations and 48 manuscripts were pulled for thorough review after screening title and abstract. Of these, nine papers met the inclusion criteria. Figure 1 highlights the selection process.

The nine human intervention studies included in this review were published between 2009 and 2020. They fell into four broad categories: (1) acceptability and nutritional implications of using insects as a component of complementary foods (CFs) $(\mathrm{n}=5)$; (2) impacts of insect consumption on gut microbiota $(n=1)$; (3) quality and impact of insects as a protein supplement $(n=2) ;(4)$ clinical implications of adding an insect granule supplement to routine treatment for chronic obstructive pulmonary disease (COPD) $(\mathrm{n}=1)$ (Table 1).

Eight of the studies involved randomised dietary interventions where insect consumption was compared to other treatments, a control, or a placebo. The remaining study was not randomised, but did involve feeding insect foods to human subjects to ascertain acceptability and tolerability (Bauserman et al., 2015b). None of the studies

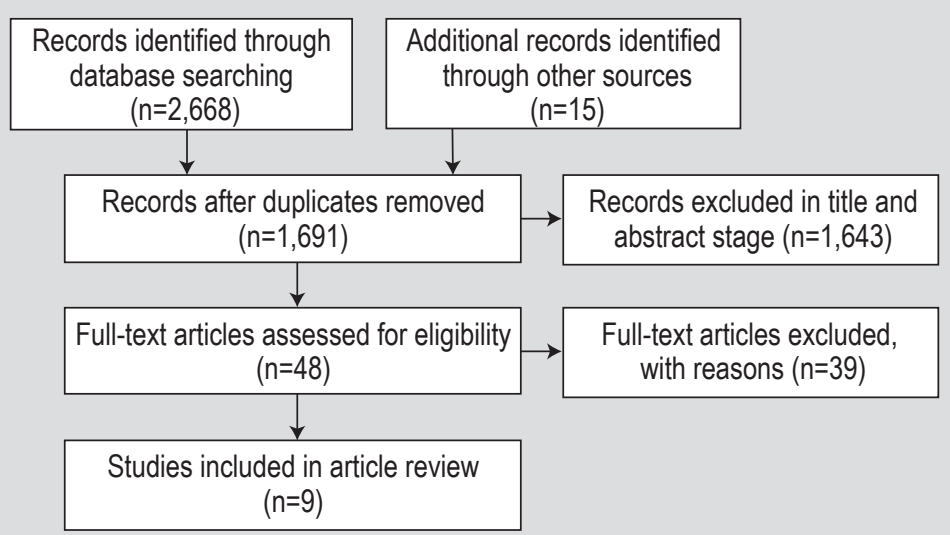

Figure 1. PRISMA flow diagram outlining screening process for literature review (modified from Moher et al., 2009). 
Table 1. Articles included for final review.

\begin{tabular}{|c|c|}
\hline Authors & Konyole et al. (2012) \\
\hline Full title & $\begin{array}{l}\text { Acceptability of Amaranth grain-based nutritious complementary foods with Dagaa fish (Rastrineobola argentea) and edible } \\
\text { termites (Macrotermes subhylanus) compared to corn soya blend plus among young children/mothers dyads in western } \\
\text { Kenya }\end{array}$ \\
\hline Insect type & Termite: Macrotermes subhylanus (Isoptera: Termitidae) \\
\hline Study design & Randomised crossover clinical trial + at home dietary intervention (acceptability study) \\
\hline Location & Makunga Sub-District Hospital, Kakamega County, Western Kenya \\
\hline Population & Healthy children (6-24 months), \\
\hline Intervention & $\begin{array}{l}\text { (1) } 150 \mathrm{ml} \text { of WinFood Classic Complementary Food Mix provided to infants for } 1 \text { day: Amaranth Grain }+10 \% \text { edible } \\
\text { termites }+3 \% \text { dagaa (small fish); (2) } 100 \mathrm{~g} \text { flour mix given to mothers to take home. [Compared to two other foods without } \\
\text { insects or fish] }\end{array}$ \\
\hline Sample & $\mathrm{n}=57$ pairs (child and mother); $\mathrm{n}=57$ consuming insects \\
\hline Duration & 1 day with 1 day washout; 4 week follow-up \\
\hline Outcomes measured & Tolerance via morbidity data; Maternal and Child Acceptability (ranking \& child consumed $>75 \%$ of serving). \\
\hline Results & Complementary food with termites was acceptable by the target population with no adverse effects found. \\
\hline Authors & Skau et al. (2015) \\
\hline Full title & $\begin{array}{l}\text { Effects of animal source food and micronutrient fortification in complementary food products on body composition, iron } \\
\text { status, and linear growth: a randomised trial in Cambodia }\end{array}$ \\
\hline Insect type & Edible spider: Haplopelma (species unspecified) \\
\hline Study design & Randomised and single-blinded, community-based dietary intervention \\
\hline Location & PeaRieng and Sithor Kandal Districts, Prey Veng province, Cambodia \\
\hline Population & Infants (6 months old) \\
\hline Intervention & $\begin{array}{l}\text { Age-based provision of rice-based complementary food products: WinFood (WF) with small fish and edible spiders. (WF } \\
\text { contained } 1.8 \mathrm{~g} \text { spiders per } 100 \mathrm{~g} \text { dry weight.) [Compared to three other formulations without spider] }\end{array}$ \\
\hline Sample & $n=419 ; n=106$ consuming insects \\
\hline Duration & 9 months \\
\hline Outcomes measured & $\begin{array}{l}\text { Changes in fat-free mass (FFM); change in plasma ferritin and soluble transferrin receptors; changes in anthropometric } \\
\text { variables, including knee-heel length. }\end{array}$ \\
\hline Results & $\begin{array}{l}\text { No difference in fat-free mass increment in insect porridge (WF) compared with control [WF: }+0.04 \mathrm{~kg}(95 \% \mathrm{Cl}: 20.20,0.28 \\
\mathrm{kg} \text { ); No effect on iron status across the treatments, however iron status deteriorated for all infants over study period for all } \\
\text { treatments. No significant differences in anthropometric measurements across treatments. }\end{array}$ \\
\hline Authors & Bauserman et al. (2015a) \\
\hline Full title & $\begin{array}{l}\text { Caterpillar cereal as a potential complementary feeding product for infants and young children: nutritional content and } \\
\text { acceptability }\end{array}$ \\
\hline Insect type & Caterpillar (species unspecified) \\
\hline Study design & Acceptability study \\
\hline Location & Rural Equateur Province of the Democratic Republic of Congo \\
\hline Population & Healthy infants (8-10 months) and their mothers \\
\hline Intervention & $\begin{array}{l}30 \mathrm{~g} \text { sachet of complementary cereal with dried, ground caterpillar fed to infants daily (actual amount of caterpillar unclear). } \\
\text { [Not randomised; no control] }\end{array}$ \\
\hline Sample & $\mathrm{n}=20$ pairs (infant and mother); $\mathrm{n}=20$ consuming insects \\
\hline Duration & 7 days \\
\hline Outcomes measured & $\begin{array}{l}\text { Child illness or symptoms as reported by the mother; Maternal acceptability (by rating); Child acceptability (by \% } \\
\text { consumed); Nutrient content of cereal; Microbiologic assays for food safety. }\end{array}$ \\
\hline Results & $\begin{array}{l}\text { Caterpillar cereal is safe for consumption (no serious side-effects), has appropriate macro- and micronutrient contents for } \\
\text { complementary feeding, and is acceptable to mothers and infants. }\end{array}$ \\
\hline
\end{tabular}


Table 1. Continued.

\begin{tabular}{|c|c|}
\hline Authors & Bauserman et al. (2015b) \\
\hline Full title & $\begin{array}{l}\text { A cluster-randomised trial determining the efficacy of caterpillar cereal as a locally available and sustainable } \\
\text { complementary food to prevent stunting and anaemia }\end{array}$ \\
\hline Insect type & Caterpillar (species unspecified) \\
\hline Study design & Cluster-randomised controlled feeding trial \\
\hline Location & Rural Equateur Province of the Democratic Republic of Congo \\
\hline Population & Infants (6 months old) \\
\hline Intervention & $\begin{array}{l}30 \text { or } 45 \mathrm{~g} \text { sachet of complementary cereal with dried, ground caterpillar fed to infants daily depending on age (actual } \\
\text { amount of caterpillar unclear). [Compared with control that did not receive food] }\end{array}$ \\
\hline Sample & $n=222 ; n=111$ consuming insects \\
\hline Duration & 12 months \\
\hline Outcomes measured & $\begin{array}{l}\text { Compliance with feeding; } 24 \text { hour dietary recall; Feeding practices via Infant and Child Feeding Index (ICFI); } \\
\text { anthropometric measurements on infants at 6, 9, } 12 \text { and } 18 \text { months of age; blood indices of Fe status at } 18 \text { months. }\end{array}$ \\
\hline Results & $\begin{array}{l}\text { Supplementation with caterpillar cereal did not reduce prevalence of stunting at } 18 \text { months; Infants who consumed } \\
\text { caterpillar cereal had higher } \mathrm{Hb} \text { concentrations than the control group ( } 10.7 \mathrm{vs} 10.1 \mathrm{~g} / \mathrm{dl}, P=0.03 \text { ) and fewer were anaemic } \\
\text { ( } 26 \text { vs } 50 \%, P=0.006 \text { ); no difference in estimates of body Fe stores ( } 6.7 \mathrm{vs} 7.2 \mathrm{mg} / \mathrm{kg} \text { body weight, } P=0.44 \text { ). }\end{array}$ \\
\hline Authors & Stull et al. (2018) \\
\hline Full title & Impact of edible cricket consumption on gut microbiota in healthy adults, a double-blind, randomised crossover trial \\
\hline Insect type & Tropical house cricket: Gryllodes sigillatus F. Walker (Orthoptera: Gryllidae) \\
\hline Study design & Crossover clinical trial, double blind, randomised \\
\hline Location & Colorado, USA \\
\hline Population & Healthy adults (>18 years) \\
\hline Intervention & $25 \mathrm{~g}$ whole cricket powder added to diet daily via muffin and shake. [Compared with control foods without insects] \\
\hline Sample & $n=20 ; n=20$ consuming insects \\
\hline Duration & 2 week intervention ( 6 weeks total with washout and control) \\
\hline Outcomes measured & $\begin{array}{l}\text { Digestive health questionnaire (self-report); Comprehensive Metabolic Panel; Microbiome changes via faecal DNA; } \\
\text { Changes in Microbial Metabolism; Faecal Triglycerides; Measures of Inflammation. }\end{array}$ \\
\hline Results & $\begin{array}{l}\text { Cricket consumption is tolerable and non-toxic at the studied dose; no changes in excreted bile acids or faecal triglycerides; } \\
\text { increase in abundance of the probiotic bacterium Bifidobacterium animalis ( } 5.7 \text { fold); associated with decrease of other } \\
\text { bacterium. Cricket consumption also associated with reduced plasma TNF-a. Suggestive of improved gut health and } \\
\text { reduced systemic inflammation. }\end{array}$ \\
\hline Authors & Vangsoe et al. (2018a) \\
\hline Full title & Effects of insect protein supplementation during resistance training on changes in muscle mass and strength in young men \\
\hline Insect type & Lesser mealworm: Alphitobius diaperinus Panzer (Coleoptera: Tenebrionidae) \\
\hline Study design & Clinical trial, randomised, controlled, single-blinded trial \\
\hline Location & Aarhus University, Denmark \\
\hline Population & Healthy young men (18 to 30 years) \\
\hline Intervention & $\begin{array}{l}\text { Ingested an insect-protein bar containing } 0.4 \mathrm{~g} \text { protein } / \mathrm{kg}(\mathrm{Pro}, \mathrm{n}=9) \text { within } 1 \mathrm{~h} \text { after each training and } 1 \mathrm{~h} \text { before night } \\
\text { sleep on training days. [Compared to isocaloric carbohydrate control bar] }\end{array}$ \\
\hline Sample & $\mathrm{n}=18 ; \mathrm{n}=9$ consuming insects \\
\hline Duration & 8 weeks (resistance training $4 /$ week) \\
\hline Outcomes measured & $\begin{array}{l}\text { Strength (leg press and bench press); body composition (via whole-body dual-energy X-ray absorptiometry); dietary } \\
\text { records were obtained (three-day registration periods) before and during the intervention period. }\end{array}$ \\
\hline Results & $\begin{array}{l}\text { No significant differences in body composition and muscle strength improvements observed; compliance indicative of } \\
\text { tolerability. }\end{array}$ \\
\hline
\end{tabular}


Table 1. Continued.

\begin{tabular}{|c|c|}
\hline Authors & Vangsoe et al. (2018b) \\
\hline Full title & Ingestion of insect protein isolate enhances blood amino acid concentrations similar to soya protein in a human trial \\
\hline Insect type & Lesser mealworm: A. diaperinus Panzer (Coleoptera: Tenebrionidae) \\
\hline Study design & Randomised cross-over study \\
\hline Location & Aarhus University, Denmark \\
\hline Population & Healthy young men (18 to 30 years) \\
\hline Intervention & $25 \mathrm{~g}$ of crude insect protein ingested postprandially. [Compared to whey, soya, or water placebo] \\
\hline Sample & $n=6 ; n=6$ consuming insects \\
\hline Duration & 4 days \\
\hline Outcomes measured & $\begin{array}{l}\text { Amino acid concentration in blood before and } 0 \mathrm{~min}, 20 \mathrm{~min}, 40 \mathrm{~min}, 60 \mathrm{~min}, 90 \mathrm{~min} \text {, and } 120 \mathrm{~min} \text { determined using } 1 \mathrm{H} \\
\text { NMR spectroscopy. }\end{array}$ \\
\hline Results & $\begin{array}{l}\text { Ingestion of whey, soya, and insect protein isolates increased blood concentrations of amino acids (AA) over a } 120 \text { min } \\
\text { period (whey > insect = soya). Insect protein induced blood AA concentrations similar to soya protein. Higher blood AA } \\
\text { concentrations at } 120 \text { min post ingestion was observed for insect protein, suggesting it is a 'slow' digestible protein source. }\end{array}$ \\
\hline Authors & Konyole et al. (2019) \\
\hline Full title & $\begin{array}{l}\text { Effect of locally produced complementary foods on fat-free mass, linear growth, and iron status among Kenyan infants: a } \\
\text { randomised controlled trial }\end{array}$ \\
\hline Insect type & Termites: Macrotermes subhylanus (Isoptera: Termitidae) \\
\hline Study design & Randomised and double-blind, controlled trial \\
\hline Location & Mumias Sub-County in Kakamega County, Western Kenya \\
\hline Population & Infants (6 months old) \\
\hline Intervention & $\begin{array}{l}\text { Provision of: WinFood Classic (WFC) }(71 \% \text { grain amaranth, } 10.4 \% \text { corn, } 0.6 \% \text { soyabean oil, } 5 \% \text { sugar, } 10 \% \text { edible } \\
\text { termites, and } 3 \% \text { small fish dry weight); given in age-adjusted daily rations. [Compared to two other foods without insects] }\end{array}$ \\
\hline Sample & $n=499$ pairs (mother and infants); $n=165$ consuming insects \\
\hline Duration & 9 months \\
\hline Outcomes measured & $\begin{array}{l}\text { FFM accrual, linear growth, and iron status; Changes in FFM, length, plasma ferritin, plasma transferrin receptors, and } \\
\text { haemoglobin from } 6 \text { to } 15 \text { months of age. Secondary outcomes: change in weight, MUAC, head circumference, skinfolds, } \\
\text { weight. }\end{array}$ \\
\hline Results & $\begin{array}{l}\text { WFC insect food was associated with weight gain over the } 9 \text { months, predominantly fat free mass. Fat mass was also } \\
\text { preserved during the } 9 \text {-month intervention on all diets. WFC did not differ from the other complementary foods or controls } \\
\text { in terms of weight gain or mass. Plasma ferritin decreased, whereas plasma transferrin receptors increased in all three } \\
\text { groups over the } 9 \text { months indicating an overall deterioration in iron status. }\end{array}$ \\
\hline Authors & Hu et al. (2020) \\
\hline Full title & $\begin{array}{l}\text { Effects of compound Caoshi silkworm granules on stable COPD patients and their relationship with gut microbiota: a } \\
\text { randomised controlled trial }\end{array}$ \\
\hline Insect type & Caoshi silkworm (species unspecified) \\
\hline Study design & Randomised controlled trial \\
\hline Location & Jinhua Hospital of Zhejiang University, China \\
\hline Population & Adults $40-80$ with COPD grades II and III and history of 2 or more prior exacerbations \\
\hline Intervention & $\begin{array}{l}\text { Routine COPD treatment plus Compound Caoshi Silkworm Granules (CCSGs) containing } 30 \mathrm{~g} \text { silkworm and } 5 \mathrm{~g} \\
\text { Astragalus, once per day. These granules were given orally, one bag at a time and once a day. [Compared to a control } \\
\text { without CCSGs] }\end{array}$ \\
\hline Sample & $n=40 ; n=20$ consuming insects \\
\hline Duration & 3 months \\
\hline Outcomes measured & $\begin{array}{l}\text { St. George's Respiratory Questionnaire (SGRQ) score and lung function. Microbial abundance from stool samples } \\
\text { analysed using } 16 \text { s rRNA sequencing before treatment. }\end{array}$ \\
\hline Results & $\begin{array}{l}\text { Safe treatment. Individuals treated with CCSGs showed improved SGRQ scores. No difference in forced expiratory volume } \\
\text { / forced vital capacity. Baseline abundance of gut microbiota in patients with the top } 10 \text { SGRQ scores differed from the } \\
\text { abundance of gut microbiota in those with the lowest } 10 \text { SGRQ scores. CCSGs can be considered effective for patients } \\
\text { with stable COPD, and gut microbiota may be a new target. }\end{array}$ \\
\hline
\end{tabular}


controlled or tracked the entire diet of study participants. Eight studies utilised processed insects integrated into another food - a complementary cereal (Bauserman et al., 2015a,b; Konyole et al., 2012, 2019; Skau et al., 2015), smoothie and muffin (Stull et al., 2018), protein bar (Vangsoe et al., 2018a), or drink (Vangsoe et al., 2018b). One study provided $30 \mathrm{~g}$ of silkworm 'granules' daily, but processing methods for this product were not specified $(\mathrm{Hu}$ et al., 2020). The primary subjects were children $(\mathrm{n}=1,170)$. Healthy adults were the next most represented group $(n=44)$ followed by adults with confirmed COPD $(n=40)$. Children and individuals with severe health complications that could compromise the result of these studies were excluded.

None of the studies reported severe adverse health outcomes or a significant increase in morbidity or mortality with insect consumption, even for vulnerable populations. Two studies measured only basic health outcomes, such as tolerance via reported morbidity, which are difficult to interpret and generalise (Bauserman et al., 2015b; Konyole et al., 2012). However, all studies on CFs confirmed that insects are a safe addition to the diet for children. Overall, insect consumption was associated with predominantly positive or neutral results.

\section{Insects in complementary feeding and impacts on nutritional status}

The majority ( 5 out of 9) of human intervention studies evaluated insects as a novel supplement to CF for infants (6 months) and young children (up to 24 months). Two studies took place in Kenya, two in the Democratic Republic of Congo (DRC), and one in Cambodia. Outcomes included anthropometric measurements, acceptability and tolerance, and iron status. All of these studies assessed health impacts of adding insects, along with other locally available ingredients, to CFs. Overall, results suggest insects are an acceptable ingredient in CFs; insect-fortified CFs are comparable to existing CFs. Other observed improvements were not consistent across studies.

Bauserman et al. (2015a) conducted a clusterrandomised trial in DRC to determine the effectiveness of complementary cereal including caterpillars (species unspecified) to reduce stunting and anaemia in 175 infants (treatment group $n=91$ ). While caterpillar-supplemented cereal did not reduce the prevalence of stunting in children over 12 months relative to a control group (who ate regular diet), caterpillar consumption was associated with an increase in haemoglobin concentrations (Hb levels 10.7 $\mathrm{g} / \mathrm{dl}$ in treatment, $10.1 \mathrm{~g} / \mathrm{dl}$ in control, $P=0.03$ ) and lower anaemia rates (26\% in treatment versus $50 \%$ control) (Bauserman et al., 2015a).

Building from an acceptability study in 2012, Konyole et al. (2019) compared three CFs: (1) WinFood Classic (WFC), a germinated amaranth, maize, and fish product fortified with $10 \%$ termites by dry weight, Macrotermes subhylanus (Isoptera: Termitidae); (2) WinFood Lite (WFL), another germinated amaranth and corn-based food not containing insects but supplemented with micronutrients; and (3) cornsoya blend $(\mathrm{CSB}+)$, a control corn and soya blend with a vitamin premix. Infants eating all three foods gained weight and there were no differences in body composition (fat free body mass or fat mass) over the 9-month intervention. Weight gained across all groups was primarily fat free body mass. Compared with the CSB++ control, both WFC (with termites) and WFL (with micronutrients) were associated with a decrease in plasma ferritin (WFC $0.6 \mu \mathrm{g} / \mathrm{l}$ (95\% CI $[0.4,0.8])$ and an increased in plasma transferrin receptors (WFC 3.3 mg/l (95\% CI [1.7, 4.9]). The deterioration in iron status was slightly more pronounced among children who ate the termite-fortified food (WFC). Including insects and fish did not impact body composition or promote growth differently than the micronutrient fortified WFL or CSB+ control. Given that none of the CFs improved iron nutritional status, the authors speculate that environmental factors, such as exposure to hazards, enteric disfunction, malaria, and/or breastfeeding may be playing a role in iron absorption (Konyole et al., 2019).

In a similar randomised, single-blinded, community-based trial, Skau et al. (2015) demonstrated weight gain in infants who consumed pre-cooked semi-instant porridge with edible spiders (Haplopelma species unspecified). Here, infants were fed one of four treatments: WinFood (rice fortified with fish and edible spiders), WFL (rice fortified with small fish only), CSB+ (fortified corn-soya blend), and $\mathrm{CSB}++$ (fortified corn-soya blend with $8 \%$ dried skimmed milk). No differences in growth across the four treatments were observed, including changes in fat free body mass and fat mass. No differences in plasma ferritin and soluble transferrin receptor were found between the interventions. However, the WF group had a marginally smaller change in haemoglobin than $\mathrm{CSB}++$ control, and a higher prevalence of anaemia in infants who received the WinFood spider cereal compared to the WFL and the $\mathrm{CSB}++$ corn-soya control (fortified with skim milk) was observed. Anaemia in the insect treatment group was 53.7\%, whereas the WinFood Lite was 35.2\% and the control was $35.2 \%$. However, anaemia increased across all intervention groups during the study period, likely due to inadequate initial supply of iron in all treatment foods. Overall, locally produced CFs containing edible spiders did not differ from the existing fortified corn-soya blend products.

It is difficult to conduct dietary interventions in food insecure contexts. Not surprisingly, the quality of these complementary feeding trials varied. Some began with heterogeneous baseline participant populations and the full sample of nine studies utilised varying measures of anthropometry. Moreover, environmental factors and 
other variables that could impact iron status were not measured. However, Konyole et al. (2019) and Skau et al. (2015) recruited children of similar ages and included insect-free comparison treatment arms.

\section{Medicinal properties of edible insects}

One study explored potential medicinal effects of edible insects. Silkworms have been used historically in traditional Chinese medicine to treat a variety of health conditions, including COPD (Hu et al., 2020; Li et al., 2017). Hu et al. (2020) investigated the impacts of taking compound Caoshi silkworm granules (CCSGs), in addition to routine treatment, on COPD patient symptoms and lung function for 3 months. Results were compared with patients who received only routine care. Each CCSG packet given to patients contained $30 \mathrm{~g}$ Caoshi silkworm (species unspecified) along with $5 \mathrm{~g}$ Astragalus medicinal herb. There was no significant difference in the incidence of adverse events between the two groups $(P>0.05)$. Although ingesting silkworm granules did not change measures of lung function, results suggest that it may have improved symptomology, measured via St. George's respiratory questionnaire (SGRQ) $(P=0.02)$. The mechanism for action is not clear but may be linked to baseline microbiota among patients. Importantly, it is not feasible to differentiate effects of the silkworm from effects of the Astragalus herb. Additionally, it is likely that other studies reporting medicinal efficacy of silkworms or edible insects are reported in the literature but may not appear in English language journals.

\section{Insects and the microbiome}

Only one study in this review assessed the potential for insects to serve as modulators of gut microbiota. In a double-blind, crossover trial, Stull et al. (2018) measured the health impacts of consuming 25/g of tropical house cricket, Gryllodes sigillatus F. Walker (Orthoptera: Gryllidae), per day on healthy adults. Whole ground cricket consumption did not result in toxicity, cause gastrointestinal distress, or yield global disruptions to gut microbiota. Only one small metabolic difference was detected: a slight increase of alkaline phosphatase (ALP) with cricket consumption (95\% CI (0.11-0.399) $P<0.05)$. Low ALP levels are sometimes associated with malnutrition or malabsorption. However, all participants stayed within normal ALP ranges. No changes were observed across treatment groups in lipid metabolism or phyla-level microbiota composition. Only one significant change in inflammation was observed: tumour necrosis factor alpha was lower after cricket consumption relative to the control $(-0.525$ (95\% CI $(-0.93--0.12 ; P<0.05)$ (Stull et al., 2018).
Five bacterial taxa were significantly increased after cricket consumption and ten were decreased. Little is known regarding all of these taxa, however cricket supplementation (containing $\sim 2 \mathrm{~g} /$ day chitin) was associated with a 5.7 fold increase in faecal levels of the probiotic species, Bifidobacterium animalis, a 4-fold decrease in faecal Lactobacillus, and a 3.5-fold decrease in genus Acidaminococcus relative to the control (Stull et al., 2018). Increased levels of $B$. animalis could benefit health, especially through pathogen inhibition. A reduction in probiotic Lactobacillus reuteri, is not desirable, but the authors speculate that chitooligosaccharides may inhibit lactic acid producing bacteria (LAB) and the dietary fibre present in the control diet may have promoted LAB growth. Reductions in Acidaminococcus may be desirable, given its association with growth deficits in infants (Gough et al., 2015).

These results are suggestive of potential gastrointestinal and systemic health benefits associated with consuming crickets. However, additional placebo-controlled human feeding trials, along with more in vitro studies, are needed to determine mechanisms and long-term health impacts of insects and their component parts on gut microbiota (specifically chitin, specific amino acids, and unsaturated fatty acids).

Interestingly, $\mathrm{Hu}$ et al. (2020) also considered that microbiota could play a role in how insects impact health via the gut-lung axis. The authors divided participants who consumed silkworm into two groups according to their SGRQ scores (top 10 and bottom 10) and compared their microbiota components at baseline. Significant differences across species value, Shannon value, top 10 levels of phylum, and heatmap of functional predictions were observed. Faecal microbiota may play a regulatory role during administration of silkworm granules, but this is not yet understood.

\section{Insect protein quality}

Two studies investigated the quality and utility of insect protein isolate in healthy men. Neither reported unique or novel properties of insect protein. In the first, Vangsoe et al. (2018a) investigated the effect of a dietary supplement of insect protein from the lesser mealworm, Alphitobius diaperinus Panzer (Coleoptera: Tenebrionidae), on muscle hypertrophy and strength gains during prolonged resistance training compared to an isocaloric carbohydrate supplement. No dietary restrictions were placed on participants. Fat- and bone-free mass improved with both treatments across the study period. No differences in body composition or muscle strength gains were observed between groups. Although the insect protein treatment group consumed more protein on training days than 
the carbohydrate group, participants in both groups ate adequate protein outside the intervention. Energy balance variation might explain why no differences in hypertrophy or strength were detected between groups. Ultimately, the authors attribute the change in fat- and bone-free mass to the training program itself and energy consumption, rather than insect protein-supplementation.

In the second study, Vangsoe et al. (2018b) investigated the quality of insect protein from the lesser mealworm by comparing postprandial amino acid availability and blood amino acid profiles after participants consumed protein isolate from whey, soya, or insects. Six healthy men were randomised to consume $25 \mathrm{~g}$ of protein treatment or a water placebo on four different days. Blood samples were taken before ingesting protein, at the time of ingestion, and then 20, 40, 60, 90, and 120 minutes after. Results indicated a significant rise in blood concentrations of essential and branched-chain amino acids, as well as leucine, over the time period for all protein supplements. This change was greatest for whey, with soya and insects comparable to one another $(P<0.05)$. Insect protein behaved similar to soya protein. Higher amino acid concentrations beyond the 120 min period were observed with insect protein consumption, indicating that insects may be considered a slow digestible protein. Insect protein isolate did not exhibit superior or unique characteristics compared to plant-based soya protein.

\section{Discussion}

The results of this review indicate a dearth of published human intervention studies investigating edible insects. From those published, entomophagy appears to be safe at the studied doses and offer several potential benefits to human health. Results should not be extrapolated given the number of species studied, small sample sizes, and limited health outcomes measured. Due to the small number of studies per species, no valuable comparisons across insect species can be made at this time. Only one study analysed health outcomes from insect consumption alone and not in combination with other foods (Vangsoe et al., 2018b). Since none of the studies controlled or monitored the complete diet of participants, it is difficult to determine which outcomes resulted from the insects versus other food ingredients or the combination thereof. There is a true need for additional human intervention studies and clinical trials measuring the health impacts of entomophagy.

It would be short-sighted not to put the findings of this review in context with the other extensive research on edible insects from animal studies, in vitro experiments, and nutrient analyses. This discussion contextualises the results of the systematic review and highlights other potential health impacts not yet explored through human trials.

\section{Improving nutritional status}

\section{Micronutrient deficiencies}

Insects can be a good source of several essential micronutrients, particularly minerals like potassium, calcium, copper, magnesium, manganese, phosphorous, and selenium (Finke, 2002; Rumpold and Schlüter, 2013; Schabel, 2010). Notably, they also often contain relevant concentrations of zinc and iron (Christensen et al., 2006), with several reporting iron concentrations greater than ground beef or chicken (Finke, 2002; Mwangi et al., 2018; Oonincx and Van der Poel, 2011; USDA, 2018).

The rich micronutrient content of edible insects is particularly relevant in food insecure contexts, where iron-deficiency anaemia is prevalent. As this review demonstrates, the impact of dietary insect iron on iron status is not well understood and outcomes have been inconsistent. In one study, infants that consumed caterpillar-enriched cereal for 12 months had higher iron concentrations and lower rates of anaemia than those that did not (Bauserman et al., 2015a). In two other studies, insect-fortified CFs were not associated with improvements in iron status (Konyole et al., 2019; Skau et al., 2015); however, other ingredients in these foods and/or nondietary confounders could have influenced iron status.

It remains unclear exactly how well insect iron is absorbed. It is uniquely packaged compared to iron in vertebrates or plants, containing both haem and non-haem molecules. Predominantly, insect iron is found in the non-haem form (ferritin and holoferritin), but insects also contain smaller quantities of haem iron (found in cytochromes) (Mwangi et al., 2018). Several in vitro and animal studies suggest that bioavailability of insect iron is good. A recent simulated digestion study assessed the solubility and bioavailability of both iron and zinc from several insect species and compared results with sirloin beef (Latunde-Dada et al., 2016). Iron solubility for insects was greater than steak or whole wheat flour, but bioaccessibility (ferritin concentration in Caco-2 cells) varied by species and was not uniform across foods. Adding insects to wheat flour (1:1) demonstrated better iron and zinc solubility than beef in composite mixtures. It is therefore plausible that adding insects to starch-based diets could help address deficiencies and even increase the bioavailability of native or fortified iron in the starchy foods (Mwangi et al., 2018). In a study of malnourished rats, researchers compared iron bioavailability from two insects, the house cricket, Acheta domesticus Linnaeus (Orthoptera: Gryllidae), and the palm weevil, Rhynchphorus phoenicis Fabricius (Coleoptera: Curculionidae), a positive control casein, and ferrous sulphate $\left(\mathrm{FeSO}_{4} \cdot 7 \mathrm{H}_{2} \mathrm{O}\right)$ diet. After inducing malnutrition, rats were fed supplemented diets for 14 days. During this time, an increase in haemoglobin 
relative biological value was observed with both insects, comparable to the control, indicating that these insects are an excellent source of bioavailable iron (Agbemafle et al., 2019). Another study fed palm weevil larvae enriched biscuits to female albino rats for 28 days. Rats fed palm weevil had haematological parameters similar to rats fed the control diet, but their cholesterol concentrations were slightly higher than the control group. No inflammation was observed (Ayensu et al., 2020).

Additional human and animal studies are needed to untangle these contradictory findings and further explore iron bioavailability in humans. Analyses of other variables that impact insect iron absorption, such as its release from the food matrix, effect of food preparation methods, presence of antinutrients, iron form, and systemic factors are needed.

\section{Vitamin B12}

There is some evidence that certain insects contain B vitamins such as biotin, pyridoxine, riboflavin, pantothenic acid, folate, and niacin, and B12 (cobalamin) (Nowak et al., 2014; Rumpold and Schlüter, 2013; Schabel, 2010). Major dietary sources of vitamin B12 include meat, milk, animalsourced foods, and to a lesser extent nori, nutritional yeast, and some bacteria or algae. People eating a majority plantbased diet are often at risk of deficiency. Only a handful of insects have been assessed for B12 content, and most demonstrated negligible quantities. However, the domestic house cricket has been shown to contain an impressive 8 mcg per $100 \mathrm{~g}$ fresh weight (FAO, 2017), relevant given the recommended dietary allowance for adults older than 14 is $2.4 \mathrm{mcg}$ per day (NIH, 2018). Some B vitamins are not heat stable and may decrease through processing. The content, stability, and bioavailability of insect B12 requires more research.

\section{Protein and amino acid deficiencies}

The quality of insect protein is thought to be good, but there are discrepancies in the literature regarding its digestibility. The two relevant studies in this review did not demonstrate that insect protein from the lesser mealworm is unique or superior to other proteins. Vangsoe et al. (2018b) found that postprandial amino acid availability from insect protein isolate is comparable to soya, a high-quality plant protein. But since insects provide animal-based protein, it was expected that they would be more digestible than plantbased protein sources. A previous study in rats showed that termite protein was about $61 \%$ as digestible as casein (Phelps et al., 1975); moreover, chitin could modulate protein digestibility (Churchward-Venne et al., 2017). It is possible that processing insects to remove chitin may improve digestibility.
On the contrary, other studies have found variations in insect protein digestibility by species, but relatively high overall levels. In a study of 87 species, protein digestibility ranged from 76 to $96 \%$, higher than most plant proteins but lower than eggs (95\%) or beef (98\%) (Ramos-Elorduy et al., 1997). Another study measured protein digestibility of the farmed yellow mealworm, Tenebrio molitor Linnaeus (Coleoptera: Tenebrionidae), and house crickets fed to rats. Digestibility for both raw (84-92\%) and heat-treated insects (84-90\%) was high (Poelaert et al., 2018). Others have reported insects having superior or equivalent protein quality compared with soya (Finke et al., 1989; Yi et al., 2013).

Regardless of overall protein digestibility, supplementing inadequate diets with specific amino acids that are deficient could be one means to combat PEM. For example, lysine is the most limiting essential amino acid in corn grain (Alan, 2009). People that get more than $50 \%$ of their daily calories from eating corn, such as many communities across Southern Africa, are at risk of developing PEM (Nuss and Tanumihardjo, 2011). Numerous species of insects contain relevant quantities of lysine (Oibiokpa et al., 2018; Sogbesan and Ugwumba, 2008; Stull et al., 2019). Insects are also thought to supply important amino acids that are deficient in other cereal, tuber, and legume-based diets (Bukkens, 2005; Manditsera et al., 2019; Nadeau et al., 2015; Van Huis et al., 2013). A recent study of malnutrition recovery in mice indicated that a tropical house cricket-based diet was comparable to a both a peanut- and milk-based diet in terms of body weight recovery, but differed in impacts on immune and metabolic markers (Bergmans et al., 2020). Parker et al. (2020) assessed nutrient content of raw, roasted, and groundnut mixed palm weevil larvae in Ghana to supplement CFs. Mixing larvae in all forms with other local foods (e.g. potatoes) was found to supply otherwise deficient lysine to the diet and generate more complete amino acid profiles, which could enhance CFs to help meet nutritional requirements for children (Parker et al., 2020).

It should be noted that insects are not homogenous, and protein and amino acid values in insects do differ by order, species, and rearing conditions. Processing and cooking methods could damage amino acids; Sulphur-containing amino acids such as methionine are particularly susceptible to damage via oxidation depending on temperature and duration of exposure (Hendriks, 2018). More research is needed to understand the quality of insect proteins, the impact of processing on amino acids, and the bioavailability of proteins from insects in the diet. 


\section{Insect chitin and derivatives}

Insects may have health impacts beyond simply providing nutrients; one plausible mechanism stems from the utilisation of insect fibre - a non-nutrient - in the gut. The relationship between insects and the microbiome is not well understood. Only one study in this review assessed impacts of insect consumption on the microbiome (Stull et al., 2018). Another speculated as to interactions between the microbiome and health effects from silkworm consumption on COPD patients ( $\mathrm{Hu}$ et al., 2020). However, there are several reasons to hypothesise that insects may modulate gut microbiota and therefore indirectly influence health.

Unlike all other animal foods, edible insects contain meaningful levels of dietary fibre, predominantly in the form of chitin, an insoluble fibre. Chitin, a modified polysaccharide (poly-beta-1,4-N-acetylglucosamine) with a structure analogous to indigestible cellulose, is the primary component of the insect exoskeleton, respiratory linings, digestive and excretory systems (Clark and Smith, 1935). Through deacetylation, chitin can change structure into more soluble forms, namely chitosan or chitooligosaccharides (COS). COS from other sources are known prebiotics, so it is possible that insect chitin and derivatives could affect human health by selectively promoting the growth of beneficial bacterial species in the intestines.

In the first clinical trial to assess the impact of whole insect consumption on gut microbiota, daily consumption was associated with an increase in in the abundance of a beneficial probiotic bacterial species, $B$. animalis (Stull et al., 2018). This particular bacterium has been studied extensively. It helps to inhibit pathogens such as Escherichia coli and Salmonella in the gut (Collado et al., 2007; Martins et al., 2009). The mechanism of action remains unclear, however. Recent studies demonstrate that several human cell types do produce chitinases (including gastric chitinases) and chitinase-like proteins (Mack et al., 2015; Paoletti et al., 2007) that could break down chitin. In primates, chitinase evolution has been linked to insectivory (Janiak et al., 2017). No evidence clearly explains how chitin is broken down (deacetylated or otherwise) during human digestion, however.

Laboratory and animal studies have confirmed the potential prebiotic effect of insects and indicated that insects can modify the microbiome. Using an in vitro simulation model with T. molitor insect flour, De Carvalho et al. (2019) showed that $T$. molitor insect flour enhanced growth of almost all studied probiotic bacteria, increased production of short chain fatty acids, and helped maintain culture viability even while under nutritional stress (De Carvalho et al., 2019). In another in vitro study, digestion resistant constituents from grass grub larvae (predominantly chitin) were fermented in faecal batch cultures and were associated with an increase in Faecalibacterium, which is thought to be beneficial for its anti-inflammatory properties and potential to improve gut health (Young et al., 2020). Animal feeding trials have exhibited similar and more pronounced effects, as in these studies insects can make up a large portion of a controlled diet. Laying hens fed black soldier fly, Hermetia illucens Linnaeus (Diptera: Stratiomyidae) larvae meal (in place of soyabean meal) experienced dramatic changes in caecal microbiota, pointing to a prebiotic effect (Borrelli et al., 2017).

Conversely, insect chitin could also inhibit the growth of bacteria, fungi, or other organisms in the gut. For example, a decrease in faecal probiotic Lactobacillus was also observed in healthy adults after 2 weeks of consuming cricket (Stull et al., 2018). This is not altogether surprising, given that in laboratory studies, COS was shown to inhibit the growth of Lactobacillus spp. (Jeon et al., 2001). In industry, chitosan has been used to prevent beer spoilage by preventing Lactobacillus growth (Gil et al., 2004). Antibiotic and antimicrobial properties could also be positive, however. For example, chitin derivatives from various sources have been shown to inhibit growth of pathogens and other less desirable enteric organisms, such as Clostridium perfringens (Tsai and Hwang, 2004) and E. coli (Chien et al., 2016; Selenius et al., 2018) and even Vibrio cholera, and Salmonella typhimurium (Fernandes et al., 2008)

Additionally, some evidence suggests that insect chitin could also stimulate activation of innate and adaptive immune cells (Komi et al., 2018), improve glucose tolerance and insulin secretion (Zheng et al., 2018), and exhibit anticancer, antiviral, and antifungal activity (Piccolo et al., 2017). Animal studies indicate that chitin could help control lipid absorption in the intestines, lower total plasma cholesterol and low-density lipoprotein (LDL)-cholesterol, while increasing excretion of triglycerides in faeces (Zacour et al., 1992). Many of these studies are exploratory and more research is needed to understand the properties of insect chitin and all possible health impacts from consumption. Additionally, we need to better appreciate how insects interact with the complex gut microbiome.

\section{Other potential benefits}

\section{Bioactive compounds}

Insects may offer other benefits due to the presence of bioactive compounds. Although none of the articles included in this review specifically investigated bioactive compounds, there is some evidence that these compounds could reduce health risks and boost immune function. For example, insects may contain bioactive compounds that could strengthen immune system function or reduce health risks (Roos and Van Huis, 2017). Specifically, 
several publications have confirmed that insects are a good source of biologically active peptides (Nongonierma and FitzGerald, 2017; Wu et al., 2015; Zielińska et al., 2017a,b), which have possible impacts discussed below.

\section{Hypertension and cardiovascular disease}

High blood pressure is a key risk factor for stroke, heart attack, chronic kidney disease, disability, and premature death; however it is largely considered preventable (Mills et al., 2016). The angiotensin-converting enzyme (ACE) causes vasoconstriction and subsequently increases blood pressure. Excessive activity of ACE plays a role in regulating electrolyte and water balance, as well as blood pressure (Brunner et al., 1972). Thus, inhibiting ACE activity using drugs (or nutraceuticals) is a common treatment for cardiovascular disease.

ACE inhibitory peptides have been identified in in handful of edible insects, and activity via insect peptides is comparable to some bioactive peptides found in other animal protein sources (Cito et al., 2017a,b). In vitro studies have shown that peptides from the silkworm, Bombyx mori Linnaeus (Lepidoptera: Bombycidae), have inhibitory activity against ACE as well as the enzyme $\alpha$-glucosidase (Vercruysse et al., 2005; Wu et al., 2015; Zhang et al., 2016). These studies suggest that insect protein or its hydrolysates could serve as a functional ingredient in supplementary therapeutic foods to treat hypertension or control cholesterol, but human studies are needed.

\section{Metabolic syndrome}

Bioactive peptides derived from insects may inhibit enzyme activity associated with metabolic syndrome (Zielinska et $a l ., 2020)$. Antioxidant and anti-inflammatory peptides in several insects have been observed (Zielińska et al., 2017a), and these peptides have demonstrated antiradical, chelating ions, lipoxygenase, and cyclooxygenase- 2 activity. A follow-on study demonstrated that thermal processing the desert locust, Schistocerca gregaria Forskål. (Orthoptera: Acrididae), may boost peptide properties (Zielinska et al., 2020).

\section{Type 2 diabetes and obesity}

Type 2 diabetes is often complicated by hypertension, which is also a risk factor for stroke, heart attack, heart failure, and kidney disease (Sowers and Epstein, 1995). There are several ways that insects could help manage type 2 diabetes. Synthetic ACE inhibitors are often used to treat hypertension with type 2 diabetes, but their side effects are unpleasant and natural product alternatives are desired (Wu et al., 2015). ACE inhibitors from insects may be useful. Inhibiting enzyme $\alpha$-glucosidase is another therapeutic target for suppressing hyperglycaemia in type 2 diabetes
(Zhang et al., 2016), and only a handful of $\alpha$-glucosidase inhibitors for diabetes have been identified. Recent research illustrates that peptide fractions from desert locusts could inhibit $\alpha$-glucosidase to help treat type 2 diabetes (Zielinska et al., 2020). Moreover, glycosaminoglycan derived from the two-spotted cricket Gryllus bimaculatus De Geer (Orthoptera: Gryllidae) has been shown to decrease blood glucose, LDL-cholesterol, and alkaline phosphatase levels while reducing oxidative damage in diabetic mice (Ahn et al., 2019).

A few studies have investigated the impact of insects and their bioactive compounds on weight control in mice (Kim et al., 2016; Seo et al., 2017). Results have been favourable, as daily intake of yellow mealworm larvae by obese mice mitigated body weight gain. By reducing fat accumulation in the body and the concentration of triglycerides in fat cells (adipocytes), the insect powder may have contained a bioactive compound that could induce weight loss (Seo et al., 2017). Another study found that extracts of Korean horn beetle, Allomyrina dichotoma Linnaeus (Coleoptera: Scarabaeidae), can reduce endoplasmic reticulum stress when injected into the brain tissue of obese mice (Kim et al., 2016).

Insect chitin or chitosan may also impact weight. The influence of dietary chitosan supplements on body weight and fat metabolism is poorly understood. In a recent study, chitosan from fungus was associated with reductions in mean body weight and blood sugar (Trivedi et al., 2016), and a meta-analysis concluded that chitosan supplementation can yield a short- and medium-term effect on weight loss and improvement of serum lipid profiles, as well as cardiovascular factors (Moraru et al., 2018). Human studies are needed to improve our understanding in each of these three dimensions.

\section{Antioxidants}

Edible insects are a dietary source of antioxidants. In a comparison of antioxidant capacity of aqueous and liposoluble extracts from insects with olive oil and fresh orange juice, Di Mattia et al. (2019) reported that numerous insect species displayed antioxidant capacity values twoor three-fold higher. African caterpillars, grasshoppers, and crickets exhibited the highest levels of reducing power, whereas grasshoppers, silkworms, and crickets demonstrated the highest antioxidant capacity values (Di Mattia et al., 2019).

Processing insects may impact antioxidants. In a study of three species (yellow mealworm, desert locust, and tropical house cricket), processing methods impacted antioxidant and anti-inflammatory activities of the insect peptides. All insects in the study were a good source of bioactive peptides with antioxidant activity, and after digestion and 
absorption processes they exhibited high antiradical activity. Moreover, heat treatment positively affected antioxidant properties of the insect peptides (Zielińska et al., 2017a).

Insect antioxidants could also mediate oxidative stress. A study of the free radical scavenging activities of the aqueous extract of lesser banded hornet, Vespa affinis Linnaeus (Hymenoptera: Vespidae), demonstrated antioxidant potential, which could mediate therapeutic activities in conditions that are linked to oxidative stress (Dutta et al., 2016). Additionally, edible insect hydrolysates from digested dubia roach, Blaptica dubia Serville (Blattodea: Blaberidae), Madagascar hissing cockroach, Gromphadorhina portentosa Schaum (Blattodea: Blaberidae), migratory locust, Locusta migratoria Linnaeus (Orthoptera: Acrididae), superworm larvae, Zophobas morio Fabricius (Coleoptera: Tenebrionidae), and a cricket, Amphiacusta annulipes Serville (Orthoptera; Gryllidae), were assessed for free radical-scavenging activity and ability to chelate metal ions. Results demonstrated that these edible insects were a rich source of bioactive peptides with both antioxidant activity and the ability to chelate metal ions (Zielińska et al., 2017b). Reported antioxidants found in insects could help prevent molecular damage, cardiovascular disease, and oxidative stress, but human studies are needed.

\section{Health risks}

Although the studies included in this review report mostly positive or neutral health outcomes, potential health risks from insect consumption have also been identified. Allergies, food safety concerns associated with microbiological or chemical contamination, and the presence of antinutrients that could impede nutrient absorption are the primary risks currently associated with entomophagy. There is little evidence, however, of disease or parasitoid transmission to humans when insects are handled under sanitary conditions (Van Huis et al., 2013). In general, insects known to be edible are considered safe to eat if they are properly processed and handled.

\section{Allergies}

Although excluded from analyses in this review for not meeting the inclusion criteria, more than 250 articles were found that discussed or investigated insect allergens. These studies were not controlled; most were case reports of people eating insects and then falling ill, reviews, or laboratory studies assessing allergens in sera. A review by De Gier and Verhoeckx (2018) provides a comprehensive overview of case reports of allergy following insect consumption, cross-reactive and other proteins involved in insect allergy, and possible alteration of allergenic potential through processing and digestion. Testa et al. (2017) also discuss allergies in a review of possible health risks associated with entomophagy. Allergenic effects from edible insects are difficult to study (Yates-Doerr, 2014), but they have been identified to varying degrees. Insects, like other arthropods, can produce mild allergic reactions in consumers (Ayuso, 2011). There are several known antigenic determinants conserved across arthropods. Cross-reactivity between edible insects and crustaceans has been established (Belluco et al., 2013), and current data highlight the role played by arthropod pan-allergens including arginine kinase and tropomyosin (Ribeiro et al., 2018). Individuals allergic to shrimp may be more likely to be allergic to yellow mealworm than other insects (Broekman et al., 2017), and sera from people with dust mite and crustacean allergies cross-reacted with mealworm proteins (Verhoeckx et al., 2014) indicating that people with dust mite allergies may be allergic to insect proteins. Researchers also found a strong correlation between specific Immunoglobulin E (IgE) levels in the two-spotted cricket, shrimp-specific IgE levels, and responses, indicating that crickets may induce a reaction in individuals with a crustacean allergy (Kamemura et al., 2018). Although uncommon, extreme reactions to edible insects can cause dangerous or fatal anaphylaxis. Anaphylactic shock has been observed with entomophagy in rare cases (Ji et al., 2008; Kung et al., 2011; Okezie et al., 2010).

It is reasonable to recommend that individuals with known shellfish or mollusc allergies avoid entomophagy (Testa et al., 2017). Occupational exposures leading to allergies also pose a threat to people who work closely with edible insects (Mlcek et al., 2014). Double-blind and placebocontrolled trials, food challenges, and research on molecular mechanisms are needed to confirm and further explore this topic.

\section{Food safety}

There is no evidence that insect eating is accompanied by more health hazards than eating other animal products (Mezes, 2018). Like all meat products, insects should be properly processed to ensure food safety. Heat treatments are advised to reduce risks (Vandeweyer et al., 2018). Microbial contamination is of particular concern at specific stages of the value chain, including processing, storage, and transportation. Under certain conditions, insect microflora can facilitate the growth of hazardous microorganisms including Enterobacteriaceae (Klunder et al., 2012) known to cause food borne illness. Insects can be contaminated via improper handling and processing (Opara et al., 2012) and bacterial spores may survive some cooking methods (Ter Beek and Brul, 2010). Therefore, proper processing, handling, and storage at all times is required to destroy pathogenic microorganisms present on or inside edible insects to ensure food safety (Klunder et al., 2012; Simpanya et al., 2000; Testa et al., 2017). 
Chemical contamination and the presence of toxins can threaten food safety. Edible insects can be contaminated by pesticides in their feed source, and some species contain defence-related toxins or repellents (Rumpold and Schlüter, 2013). For example, histamine toxicity and poisoning can occur with eating fried insects. Histidine, found in high concentrations in grasshoppers and silkworm pupae, is decarboxylated by bacteria to histamine, a heat stable toxin that can cause rashes, nausea, vomiting, diarrhoea, headaches, dyspnoea, chest tightness and other complications (Chomchai and Chomchai, 2018). Caution should be followed when consuming the scarab beetle, Eulepida mashona Arrow (Coleoptera: Scarabaeidae), in Zimbabwe, which may contain cyanogenic compounds even after traditional cooking (Musundire et al., 2016b). The bioaccumulation of heavy metals in insects, such as lead in grasshoppers (Handley et al., 2007), or presence of mycotoxins such as aflatoxin may pose additional threats (Banjoy et al., 2010; Musundire et al., 2016a); however, more research is needed to quantify these risks.

\section{Malabsorption}

Antinutrients identified in some insects, such as phytate, tannin, oxalate, hydrocyanide, saponins, and alkaloids may affect and inhibit the availability of dietary nutrients (Chakravorty et al., 2016; Longvah et al., 2012; Musundire et al., 2014; Omotoso, 2006; Zhou and Han, 2006). Phytic acids, for example, may act as chelators to reduce the bioavailability of minerals. Antinutrients in insects may be absorbed from the feed source or synthesised directly by the insect; thus, rearing conditions could influence this aspect of food safety. Heating and processing may also impact anti-nutrient concentration and nutrient digestibility (El Hassan et al., 2008), and vitamins that are not heat stable (Williams et al., 2016). More research to understand what antinutrients are present in insects and investigate ways to eliminate them before consumption or mediate risk is needed.

\section{Conclusions}

Edible insects represent a diverse and relatively underexplored food group. There is ample evidence that insects are nutrient-dense, providing valuable macroand micronutrients for human diets. However, more standardised research, particularly in vivo human trials, is needed to ascertain direct health impacts of consumption. Only nine human intervention studies met inclusion criteria for this review, highlighting a dearth of available research, especially given the thousands of edible species to consider. The evidence to-date demonstrates that insects can be a valuable addition to the diet, particularly in food insecure contexts where they may supplement nutrients that are otherwise deficient. They may also serve as a valuable, lower-resource protein in wealthier contexts. Bourgeoning research on the health impacts of edible insects beyond basic nutrient provision also suggests that insect fibre and bioactive compounds may provide health benefits that warrant further investigation.

\section{Conflict of interest}

The author declares no conflict of interest.

\section{References}

Agbemafle, I., Hanson, N., Bries, A.E. and Reddy, M.B., 2019. Alternative protein and iron sources from edible insects but not Solanum torvum improved body composition and iron status in malnourished rats. Nutrients 11: 2481.

Ahn, E.-M., Myung, N.-Y., Jung, H.-A. and Kim, S.-J., 2019. The ameliorative effect of Protaetia brevitarsis larvae in HFD-induced obese mice. Food Science and Biotechnology 28: 1177-1186.

Alan, L.K., 2009. Enhancement of amino acid availability in corn grain. In: Kriz, P.D.A.L. and Larkins, P.D.B.A. (eds.) Molecular genetic approaches to maize improvement. Springer, Berlin Heidelberg, Germany, pp. 79-89.

Ayensu, J., Larbie, C., Annan, R.A., Lutterodt, H., Edusei, A., Loh, S.P. and Asiamah, E.A., 2020. Palm weevil larvae (Rhynchophorus phoenicis Fabricius) and orange-fleshed sweet potato-enriched biscuits improved nutritional status in female Wistar albino rats. Journal of Nutrition and Metabolism, Article ID: 8061365. https:// doi.org/10.1155/2020/8061365

Ayuso, R., 2011. Update on the diagnosis and treatment of shellfish allergy. Current Allergy and Asthma Reports 11: 309-316.

Baiano, A., 2020. Edible insects: an overview on nutritional characteristics, safety, farming, production technologies, regulatory framework, and socio-economic and ethical implications. Trends in Food Science \& Technology 100: 35-50.

Banjoy, A.D., Lawal, O.A., Fasunwon, B.T. and Alimi, G.O., 2010. Alkali and heavy metal contaminants of some selected edible arthropods in South Western Nigeria. American-Eurasian Journal of Toxicological Sciences 2: 25-29.

Bauserman, M., Lokangaka, A., Gado, J., Close, K., Wallace, D., Kodondi, K.-K., Tshefu, A. and Bose, C., 2015a. A clusterrandomized trial determining the efficacy of caterpillar cereal as a locally available and sustainable complementary food to prevent stunting and anaemia. Public Health Nutrition 18: 1785-1792.

Bauserman, M., Lokangaka, A., Kodondi, K., Gado, J., Viera, A.J., Bentley, M.E., Engmann, C., Tshefu, A. and Bose, C., 2015b. Caterpillar cereal as a potential complementary feeding product for infants and young children: nutritional content and acceptability. Maternal \& Child Nutrition 11: 214-220.

Belluco, S., Losasso, C., Maggioletti, M., Alonzi, C.C., Paoletti, M.G. and Ricci, A., 2013. Edible insects in a food safety and nutritional perspective: a critical review. Comprehensive Reviews in Food Science and Food Safety 12: 296-313. 
Bergmans, R.S., Nikodemova, M., Stull, V.J., Rapp, A. and Malecki, K.M.C., 2020. Comparison of cricket diet with peanut-based and milk-based diets in the recovery from protein malnutrition in mice and the impact on growth, metabolism and immune function. PLoS ONE 15: e0234559.

Black, R.E., Victora, C.G., Walker, S.P., Bhutta, Z.A., Christian, P., De Onis, M., Ezzati, M., Grantham-McGregor, S., Katz, J., Martorell, R. and Uauy, R., 2013. Maternal and child undernutrition and overweight in low-income and middle-income countries. The Lancet 382: 427-451.

Bodenheimer, F.S., 1951. Insects as human food: a chapter of the ecology of man. W. Junk, The Hague, the Netherlands, 356 pp.

Borrelli, L., Coretti, L., Dipineto, L., Bovera, F., Menna, F., Chiariotti, L., Nizza, A., Lembo, F. and Fioretti, A., 2017. Insect-based diet, a promising nutritional source, modulates gut microbiota composition and SCFAs production in laying hens. Scientific Reports 7: 16269.

Broekman, H., Knulst, A.C., De Jong, G., Gaspari, M., Den Hartog Jager, C.F., Houben, G.F. and Verhoeckx, K.C.M., 2017. Is mealworm or shrimp allergy indicative for food allergy to insects? Molecular Nutrition \& Food Research 61(9): 1601061. https://doi.org/10.1002/ mnfr.201601061

Brunner, H.R., Laragh, J.H., Baer, L., Newton, M.A., Goodwin, F.T., Krakoff, L.R., Bard, R.H. and Bühler, F.R., 1972. Essential hypertension: renin and aldosterone, heart attack and stroke. New England Journal of Medicine 286: 441-449.

Bukkens, S., 2005. Insects in the human diet. In: Paoletti, M.G. (ed.) Ecological implications of minilivestock. Potential of insects, rodents, frogs and snails. Science Publishers, Enfield, NH, USA, pp. 545-577.

Chakravorty, J., Ghosh, S., Megu, K., Jung, C. and Meyer-Rochow, V.B., 2016. Nutritional and anti-nutritional composition of Oecophylla smaragdina (Hymenoptera: Formicidae) and Odontotermes sp. (Isoptera: Termitidae): two preferred edible insects of Arunachal Pradesh, India. Journal of Asia-Pacific Entomology 19: 711-720.

Chien, R.-C., Yen, M.-T. and Mau, J.-L., 2016. Antimicrobial and antitumor activities of chitosan from shiitake stipes, compared to commercial chitosan from crab shells. Carbohydrate Polymers 138: 259-264.

Chomchai, S. and Chomchai, C., 2018. Histamine poisoning from insect consumption: an outbreak investigation from Thailand. Clinical Toxicology 56: 126-131.

Christensen, D.L., Orech, F.O., Mungai, M.N., Larsen, T., Friis, H. and Aagaard-Hansen, J., 2006. Entomophagy among the Luo of Kenya: a potential mineral source? International Journal of Food Sciences \& Nutrition 57: 198-203

Churchward-Venne, T.A., Pinckaers, P.J.M., Van Loon, J.J.A. and Van Loon, L.J.C., 2017. Consideration of insects as a source of dietary protein for human consumption. Nutrition Reviews 75: 1035-1045.

Cito, A., Botta, M., Francardi, V. and Dreassi, E., 2017a. Insects as source of angiotensin converting enzyme inhibitory peptides. Journal of Insects as Food and Feed 3: 231-240. https://doi.org/10.3920/ JIFF2017.0017

Cito, A., Dreassi, E., Frosinini, R., Zanfini, A., Pianigiani, C., Botta, M. and Francardi, V., 2017b. The potential beneficial effects of Tenebrio molitor (Coleoptera Tenebrionidae) and Galleria mellonella (Lepidoptera Pyralidae) on human health. Redia 100: 125-133.
Clark, G.L. and Smith, A.F., 1935. X-ray diffraction studies of chitin, chitosan, and derivatives. The Journal of Physical Chemistry 40: 863-879.

Collado, M.C., Grześkowiak, Ł. and Salminen, S., 2007. Probiotic strains and their combination inhibit in vitro adhesion of pathogens to pig intestinal mucosa. Current Microbiology 55: 260-265.

Collavo, A., Glew, R.H., Huang, Y.S., Chuang, L.T., Bosse, R. and Paoletti, M.G., 2005. House cricket small-scale farming. In: Paoletti, M.G. (ed.) Ecological implications of minilivestock. Potential of insects, rodents, frogs and snails. Science Publishers, Enfield, NH, USA, pp. 519-544.

De Carvalho, N.M., Walton, G.E., Poveda, C.G., Silva, S.N., Amorim, M., Madureira, A.R., Pintado, M.E., Gibson, G.R. and Jauregi, P., 2019. Study of in vitro digestion of Tenebrio molitor flour for evaluation of its heck impact on the human gut microbiota. Journal of Functional Foods 59: 101-109.

De Gier, S. and Verhoeckx, K., 2018. Insect (food) allergy and allergens. Molecular Immunology 100: 82-106.

DeFoliart, G.R., 1995. Edible insects as minilivestock. Biodiversity \& Conservation 4: 306-321.

Di Mattia, C., Battista, N., Sacchetti, G. and Serafini, M., 2019. Antioxidant activities in vitro of water and liposoluble extracts obtained by different species of edible insects and invertebrates. Frontiers in Nutrition 6: 106. https://doi.org/10.3389/ fnut.2019.00106

Dutta, P., Dey, T., Manna, P. and Kalita, J., 2016. Antioxidant potential of Vespa affinis L., a traditional edible insect species of North East India. PLoS ONE 11: e0156107.

El Hassan, N.M., Hamed, S.Y., Hassan, A.B., Eltayet, M.M. and Baiker, E., 2008. Nutritional evaluation and physiochemical properties of boiled and fried tree locust. Pakistan Journal of Nutrition 7: 325-329.

Fernandes, J.C., Tavaria, F.K., Soares, J.C., Ramos, Ó.S., João Monteiro, M., Pintado, M.E. and Xavier Malcata, F., 2008. Antimicrobial effects of chitosans and chitooligosaccharides, upon Staphylococcus aureus and Escherichia coli, in food model systems. Food Microbiology 25: 922-928.

Finke, M.D., 2002. Complete nutrient composition of commercially raised invertebrates used as food for insectivores. Zoo Biology 21: 269-285.

Finke, M.D., 2015. Complete nutrient content of four species of commercially available feeder insects fed enhanced diets during growth. Zoo Biology 34: 554-564.

Finke, M.D., DeFoliart, G.R. and Benevenga, N.J., 1989. Use of a fourparameter logistic model to evaluate the quality of the protein from three insect species when fed to rats. The Journal of Nutrition 119: 864-871.

Food and Agriculture Organisation (FAO), 2017. FAO/INFOODS food composition database for biodiversity. Version 4.0. FAO, Rome, Italy. Available at: http://www.fao.org/infoods/infoods/tables-anddatabases/faoinfoods-databases/en/

Food and Agriculture Organisation / International Fund for Agricultural Development / United Nations International Children's Emergency Fund / World Food Programme / World Health Organisation (FAO/ IFAD/UNICEF/WFP/WHO), 2020. The state of food security and nutrition in the world 2020. Transforming food systems for affordable healthy diets. FAO, Rome, Italy. 
Gil, G., Mónaco, S., Cerrutti, P. and Galvagno, M., 2004. Selective antimicrobial activity of chitosan on beer spoilage bacteria and brewing yeasts. Biotechnology Letters 26: 569-574.

Gough, E.K., Stephens, D.A., Moodie, E.E.M., Prendergast, A.J., Stoltzfus, R.J., Humphrey, J.H. and Manges, A.R., 2015. Linear growth faltering in infants is associated with Acidaminococcus sp. and community-level changes in the gut microbiota. Microbiome 3: 24 .

Handley, M.A., Hall, C., Sanford, E., Diaz, E., Gonzalez-Mendez, E., Drace, K., Wilson, R., Villalobos, M. and Croughan, M., 2007. Globalization, binational communities, and imported food risks: results of an outbreak investigation of lead poisoning in Monterey County, California. American Journal of Public Health 97: 900-906. Hendriks, W.H., 2018. 46 amino acid availability in heat-damaged ingredients. Journal of Animal Science 96: 25.

Hu, Y., Shi, Q., Ying, S., Zhu, D., Chen, H., Yang, X., Xu, J., Xu, F., Tao, F. and Xu, B., 2020. Effects of compound Caoshi silkworm granules on stable COPD patients and their relationship with gut microbiota: a randomized controlled trial. Medicine 99: e20511.

Janiak, M.C., Chaney, M.E. and Tosi, A.J., 2017. Evolution of acidic mammalian chitinase genes (CHIA) is related to body mass and insectivory in primates. Molecular Biology and Evolution 35: 607622. https://doi.org/10.1093/molbev/msx312

Jeon, Y.-J., Park, P.-J. and Kim, S.-K., 2001. Antimicrobial effect of chitooligosaccharides produced by bioreactor. Carbohydrate Polymers 44: 71-76.

Ji, K.-M., Zhan, Z.-K., Chen, J.-J. and Liu, Z.-G., 2008. Anaphylactic shock caused by silkworm pupa consumption in China. Allergy 63: 1407-1408.

Jongema, Y., 2017. List of edible insects of the world. Wageningen University \& Research, Wageningen, the Netherlands. Available at: http://tinyurl.com/mestm6p.

Kamemura, N., Sugimoto, M., Tamehiro, N., Adachi, R., Tomonari, S., Watanabe, T. and Mito, T., 2018. Cross-allergenicity of crustacean and the edible insect Gryllus bimaculatus in patients with shrimp allergy. Molecular Immunology 106: 127-134.

Kim, J., Yun, E.-Y., Park, S.-W., Goo, T.-W. and Seo, M., 2016. Allomyrina dichotoma larvae regulate food intake and body weight in high fat diet-induced obese mice through mTOR and Mapk signaling pathways. Nutrients 8: 100.

Klunder, H.C., Wolkers-Rooijackers, J., Korpela, J.M. and Nout, M.J.R., 2012. Microbiological aspects of processing and storage of edible insects. Food Control 26: 628-631.

Komi, D.E.A., Sharma, L. and Dela Cruz, C.S., 2018. Chitin and its effects on inflammatory and immune responses. Clinical Reviews in Allergy \& Immunology 54: 213-223.

Konyole, S., Kinyuru, J., Owuor, B., Kenji, G., Onyango, C., Estambale, B., Friis, H., Roos, N. and Owino, V., 2012. Acceptability of amaranth grain-based nutritious complementary foods with Dagaa fish (Rastrineobola argentea) and edible termites (Macrotermes subhylanus) compared to corn soy blend plus among young children/ mothers dyads in Western Kenya. Journal of Food Research 1: 111.
Konyole, S.O., Omollo, S.A., Kinyuru, J.N., Skau, J.K.H., Owuor, B.O., Estambale, B.B., Filteau, S.M., Michaelsen, K.F., Friis, H., Roos, N. and Owino, V.O., 2019. Effect of locally produced complementary foods on fat-free mass, linear growth, and iron status among Kenyan infants: a randomized controlled trial. Maternal \& Child Nutrition 15: e12836.

Kung, S.-J., Fenemore, B. and Potter, P.C., 2011. Anaphylaxis to Mopane worms (Imbrasia belina). Annals of Allergy, Asthma \& Immunology 106: 538-540.

Latunde-Dada, G.O., Yang, W. and Vera Aviles, M., 2016. In vitro iron availability from insects and Sirloin beef. Journal of Agricultural and Food Chemistry 64: 8420-8424.

Lesnik, J.J., 2018. Edible insects and human evolution. University Press of Florida, Gainesville, FL, USA.

Li, W., Zhang, Z., Lin, L. and Terenius, O., 2017. Antheraea pernyi (Lepidoptera: Saturniidae) and its importance in sericulture, food consumption, and traditional Chinese medicine. Journal of Economic Entomology 110: 1404-1411.

Liu, L., Johnson, H.L., Cousens, S., Perin, J., Scott, S., Lawn, J.E., Rudan, I., Campbell, H., Cibulskis, R., Li, M., Mathers, C. and Black, R.E., 2012. Global, regional, and national causes of child mortality: an updated systematic analysis for 2010 with time trends since 2000. The Lancet 379: 2151-2161.

Longvah, T., Manghtya, K. and Qadri, S.S.Y.H., 2012. Eri silkworm: a source of edible oil with a high content of $\alpha$-linolenic acid and of significant nutritional value. Journal of the Science of Food and Agriculture 92: 1988-1993.

Mack, I., Hector, A., Ballbach, M., Kohlhäufl, J., Fuchs, K.J., Weber, A., Mall, M.A. and Hartl, D., 2015. The role of chitin, chitinases, and chitinase-like proteins in pediatric lung diseases. Molecular and Cellular Pediatrics 2: 3.

Manditsera, F.A., Luning, P.A., Fogliano, V. and Lakemond, C.M.M., 2019. The contribution of wild harvested edible insects (Eulepida mashona and Henicus whellani) to nutrition security in Zimbabwe. Journal of Food Composition and Analysis 75: 17-25.

Martins, F.S., Silva, A.A., Vieira, A.T., Barbosa, F.H.F., Arantes, R.M.E., Teixeira, M.M. and Nicoli, J.R., 2009. Comparative study of Bifidobacterium animalis, Escherichia coli, Lactobacillus casei and Saccharomyces boulardii probiotic properties. Archives of Microbiology 191: 623-630.

Melo, V., Garcia, M., Sandoval, H., Jiménez, H.D. and Calvo, C., 2011. Quality proteins from edible indigenous insect food of Latin America and Asia. Emirates Journal of Food and Agriculture 23: 283-289.

Mezes, M., 2018. Food safety aspect of insects: a review. Acta Alimentaria 47: 513-522.

Mills, K.T., Bundy, J.D., Kelly, T.N., Reed, J.E., Kearney, P.M., Reynolds, K., Chen, J. and He, J., 2016. Global disparities of hypertension prevalence and control: a systematic analysis of population-based studies from 90 countries. Circulation 134: 441-450.

Mlcek, J., Rop, O., Borkovcova, M. and Bednarova, M., 2014. A comprehensive look at the possibilities of edible insects as food in Europe - a review. Polish Journal of Food and Nutrition Sciences 64: 147-157. 
Moher, D., Liberati, A., Tetzlaff, J., Altman, D.G. and The PRISMA Group, 2009. Preferred reporting items for systematic reviews and meta-analyses: the PRISMA statement. PLOS Medicine 6: e1000097. 10.1371/journal.pmed.1000097

Moraru, C., Mincea, M.M., Frandes, M., Timar, B. and Ostafe, V., 2018. A meta-analysis on randomised controlled clinical trials evaluating the effect of the dietary supplement chitosan on weight loss, lipid parameters and blood pressure. Medicina 54: 109. https://doi. org/10.3390/medicina54060109

Musundire, R., Osuga, I.M., Cheseto, X., Irungu, J. and Torto, B., 2016a. Aflatoxin contamination detected in nutrient and antioxidant rich edible stink bug stored in recycled grain containers. PLoS ONE 11: e0145914.

Musundire, R., Zvidzai, C.J., Chidewe, C., Ngadze, R.T., Macheka, L., Manditsera, F.A., Mubaiwa, J. and Masheka, A., 2016b. Nutritional and bioactive compounds composition of Eulepida mashona, an edible beetle in Zimbabwe. Journal of Insects as Food and Feed 2: 179-187. https://doi.org/10.3920/JIFF2015.0050

Musundire, R., Zvidzai, C.J., Chidewe, C., Samende, B.K. and Manditsera, F.A., 2014. Nutrient and anti-nutrient composition of Henicus whellani (Orthoptera: Stenopelmatidae), an edible ground cricket, in south-eastern Zimbabwe. International Journal of Tropical Insect Science 34: 223-231.

Mwangi, M.N., Oonincx, D.G.A.B., Stouten, T., Veenenbos, M., MelseBoonstra, A., Dicke, M. and Van Loon, J.J.A., 2018. Insects as sources of iron and zinc in human nutrition. Nutrition Research Reviews 2: 248-255.

Nadeau, L., Nadeau, I., Franklin, F. and Dunkel, F., 2015. The potential for entomophagy to address undernutrition. Ecology of Food and Nutrition 54: 200-208.

National Institutes of Health (NIH), 2018. Vitamin B12 - factsheet for health professionals. NIH, Bethesda, MD, USA. Available at: https://ods.od.nih.gov/factsheets/VitaminB12-HealthProfessional/

Nongonierma, A.B. and FitzGerald, R.J., 2017. Unlocking the biological potential of proteins from edible insects through enzymatic hydrolysis: a review. Innovative Food Science \& Emerging Technologies 43: 239-252.

Nowak, V., Persijn, D., Rittenschober, D. and Charrondiere, U.R., 2014. Review of food composition data for edible insects. Food Chemistry 193: 39-46. https://doi.org/10.1016/j.foodchem.2014.10.114

Nuss, E.T. and Tanumihardjo, S.A., 2011. Quality protein maize for Africa: closing the protein inadequacy gap in vulnerable populations. Advances in Nutrition 2: 217-224.

Oibiokpa, F.I., Akanya, H.O., Jigam, A.A., Saidu, A.N. and Egwim, E.C., 2018. Protein quality of four indigenous edible insect species in Nigeria. Food Science and Human Wellness 7: 175-183.

Okezie, O.A., Kgomotso, K.K. and Letswiti, M.M., 2010. Mopane worm allergy in a 36-year-old woman: a case report. Journal of Medical Case Reports 4: 42.

Omotoso, O.T., 2006. Nutritional quality, functional properties and anti-nutrient compositions of the larva of Cirina forda (Westwood) (Lepidoptera: Saturniidae). Journal of Zhejiang University Science B 7: 51-55.

Oonincx, D.G.A.B. and Van der Poel, A.F.B., 2011. Effects of diet on the chemical composition of migratory locusts (Locusta migratoria). Zoo Biology 30: 9-16.
Oonincx, D.G.A.B., Laurent, S., Veenenbos, M.E. and Van Loon, J.J.A., 2019. Dietary enrichment of edible insects with omega 3 fatty acids. Insect Science 27(3): 500-509. https://doi.org/10.1111/17447917.12669

Oonincx, D.G.A.B., Van Itterbeeck, J., Heetkamp, M.J.W., Van den Brand, H., Van Loon, J.J.A. and Van Huis, A., 2010. An exploration on greenhouse gas and ammonia production by insect species suitable for animal or human consumption. PLoS ONE 5: e14445.

Opara, M., Sanyigha, F.T., Ogbuewu, I.P. and Okoli, I.C., 2012. Studies on the production trend and quality characteristics of palm grubs in the tropical rainforest zone of Nigeria. Journal of Agricultural Technology 8: 851-860.

Paoletti, M.G., Norberto, L., Damini, R. and Musumeci, S., 2007. Human gastric juice contains chitinase that can degrade chitin. Annals of Nutrition and Metabolism 51: 244-251.

Parker, M.E., Zobrist, S., Lutterodt, H.E., Asiedu, C.R., Donahue, C., Edick, C., Mansen, K., Pelto, G., Milani, P., Soor, S., Laar, A. and Engmann, C.M., 2020. Evaluating the nutritional content of an insect-fortified food for the child complementary diet in Ghana. BMC Nutrition 6: 7.

Paul, A., Frederich, M., Megido, R.C., Alabi, T., Malik, P., Uyttenbroeck, R., Francis, F., Blecker, C., Haubruge, E., Lognay, G. and Danthine, S., 2017. Insect fatty acids: a comparison of lipids from three Orthopterans and Tenebrio molitor L. larvae. Journal of Asia-Pacific Entomology 20: 337-340.

Payne, C.L.R., Scarborough, P., Rayner, M. and Nonaka, K., 2016. A systematic review of nutrient composition data available for twelve commercially available edible insects, and comparison with reference values. Trends in Food Science \& Technology 47: 69-77.

Phelps, R.J., Struthers, J.K. and Moyo, S.J.L., 1975. Investigations into the nutritive value of Macrotermes falciger (Isoptera: Termitidae). Zoologica Africana 10: 123-132.

Piccolo, G., Iaconisi, V., Marono, S., Gasco, L., Loponte, R., Nizza, S., Bovera, F. and Parisi, G., 2017. Effect of Tenebrio molitor larvae meal on growth performance, in vivo nutrients digestibility, somatic and marketable indexes of gilthead sea bream (Sparus aurata). Animal Feed Science and Technology 226: 12-20.

Poelaert, C., Francis, F., Alabi, T., Megido, R.C., Crahay, B., Bindelle, J. and Beckers, Y., 2018. Protein value of two insects, subjected to various heat treatments, using growing rats and the protein digestibility-corrected amino acid score. Journal of Insects as Food and Feed 4: 77-87. https://doi.org/10.3920/JIFF2017.0003

Poore, J. and Nemecek, T., 2018. Reducing food's environmental impacts through producers and consumers. Science 360: 987-992.

Ramos-Elorduy, J., Moreno, J.M.P., Prado, E.E., Perez, M.A., Otero, J.L. and De Guevara, O.L., 1997. Nutritional value of edible insects from the State of Oaxaca, Mexico. Journal of Food Composition and Analysis 10: 142-157.

Ranganathan, J., Vennard, D., White, R., Dumas, P., Lipinski, B. and Searchinger, T., 2016. Shifting diets for a sustainable food future. World Resources Institute, Washington, DC, USA.

Ribeiro, J.C., Cunha, L.M., Sousa-Pinto, B. and Fonseca, J., 2018. Allergic risks of consuming edible insects: a systematic review. Molecular Nutrition \& Food Research 62: 1700030. https://doi. org/10.1002/mnfr.201700030 
Ritchie, H. and Roser, M., 2017. Micronutrient deficiency. Our World in Data. Available at: https://ourworldindata.org/micronutrientdeficiency

Roos, N. and Van Huis, A., 2017. Consuming insects: are there health benefits? Journal of Insects as Food and Feed 3: 225-229. https:// doi.org/10.3920/JIFF2017.x007

Rumpold, B.A. and Schlüter, O.K., 2013. Nutritional composition and safety aspects of edible insects. Molecular Nutrition \& Food Research 57: 802-823.

Schabel, H.G., 2010. Forest insects as food: a global review. Food and Agriculture Organization of the United Nations, Rome, Italy, pp. 37-64.

Selenius, O., Korpela, J., Salminen, S. and Gallego, C.G., 2018. Effect of chitin and chitooligosaccharide on in vitro growth of Lactobacillus rhamnosus GG and Escherichia coli TG. Applied Food Biotechnology 5: 163-172.

Seo, M., Goo, T.-W., Chung, M.Y., Baek, M., Hwang, J.-S., Kim, M.-A. and Yun, E.-Y., 2017. Tenebrio molitor larvae inhibit adipogenesis through AMPK and MAPKs signaling in 3T3-L1 adipocytes and obesity in high-fat diet-induced obese mice. International Journal of Molecular Sciences 18: 518. https://doi.org/10.3390/ijms18030518

Simpanya, M.F., Allotey, J. and Mpuchane, S.F., 2000. A mycological investigation of phane, an edible caterpillar of an emperor moth, Imbrasia belina. Journal of Food Protection 63: 137-140.

Skau, J., Touch, B., Chhoun, C., Chea, M., Umni, U., Makurat, J., Filteau, S., Wieringa, F., Dijkhuizen, M., Ritz, C., Wells, J., Berger, J., Friis, H., Michaelsen, K. and Roos, N., 2015. Effects of animal source food and micronutrient fortification in complementary food products on body composition, iron status, and linear growth: a randomized trial in Cambodia. The American Journal of Clinical Nutrition 101: 742-751.

Sogbesan, A.O. and Ugwumba, A.A.A., 2008. Nutritional evaluation of termite (Macrotermes subhyalinus) meal as animal protein supplements in the diets of Heterobranchus longifilis (Valenciennes, 1840) fingerlings. Turkish Journal of Fisheries and Aquatic Sciences 8: $149-158$.

Sowers, J.R. and Epstein, M., 1995. Diabetes mellitus and associated hypertension, vascular disease, and nephropathy. Hypertension 26: 869-879.

Stevens, G.A., Finucane, M.M., De-Regil, L.M., Paciorek, C.J., Flaxman, S.R., Branca, F., Peña-Rosas, J.P., Bhutta, Z.A. and Ezzati, M., 2013. Global, regional, and national trends in haemoglobin concentration and prevalence of total and severe anaemia in children and pregnant and non-pregnant women for 1995-2011: a systematic analysis of population-representative data. The Lancet Global Health 1: e16-e25.

Stull, V.J., Finer, E., Bergmans, R.S., Febvre, H.P., Longhurst, C., Manter, D.K., Patz, J.A. and Weir, T.L., 2018. Impact of edible cricket consumption on gut microbiota in healthy adults, a double-blind, randomized crossover trial. Scientific Reports 8: 10762.

Stull, V.J., Kersten, M., Bergmans, R.S., Patz, J.A. and Paskewitz, S., 2019. Crude protein, amino acid, and iron content of Tenebrio molitor (Coleoptera, Tenebrionidae) reared on an agricultural byproduct from maize production: an exploratory study. Annals of the Entomological Society of America 112: 533-543. https://doi. org/10.1093/aesa/saz024
Ter Beek, A. and Brul, S., 2010. To kill or not to kill bacilli: opportunities for food biotechnology. Current Opinion in Biotechnology 21: 168-174.

Testa, M., Stillo, M., Maffei, G., Andriolo, V., Gardois, P. and Zotti, C.M., 2017. Ugly but tasty: a systematic review of possible human and animal health risks related to entomophagy. Critical Reviews in Food Science and Nutrition 57: 3747-3759.

Trivedi, V., Satia, M., Deschamps, A., Maquet, V., Shah, R., Zinzuwadia, P. and Trivedi, J., 2016. Single-blind, placebo controlled randomised clinical study of chitosan for body weight reduction. Nutrition Journal 15: 3.

Tsai, G. and Hwang, S., 2004. In vitro and in vivo antibacterial activity of shrimp chitosan against some intestinal bacteria. Fisheries Science 70: 675-681.

United States Department of Agriculture (USDA), 2018. National nutrient database for standard reference 1, release April, 2018. USDA Agricultural Research Service, Washington, DC, USA. Available at: http://www.ars.usda.gov/ba/bhnrc/ndl

Van Huis, A., Van Itterbeeck, J., Klunder, H., Mertens, E., Halloran, A., Muir, G. and Vantomme, P., 2013. Edible insects: future prospects for food and feed security. FAO Forestry Paper no. 171. Food and Agriculture Organization of the United Nations, Rome, Italy. Available at: http://www.fao.org/docrep/018/i3253e/i3253e00.htm Vandeweyer, D., Wynants, E., Crauwels, S., Verreth, C., Viaene, N., Claes, J., Lievens, B. and Campenhout, L.V., 2018. Microbial dynamics during industrial rearing, processing, and storage of tropical house crickets (Gryllodes sigillatus) for human consumption. Applied and Environmental Microbiology 84: e00255-18.

Vangsoe, M.T., Joergensen, M.S., Heckmann, L.-H.L. and Hansen, M., 2018a. Effects of insect protein supplementation during resistance training on changes in muscle mass and strength in young men. Nutrients 10: 335. https://doi.org/10.3390/nu10030335

Vangsoe, M.T., Thogersen, R., Bertram, H.C., Heckmann, L.-H.L. and Hansen, M., 2018b. Ingestion of insect protein isolate enhances blood amino acid concentrations similar to soy protein in a human trial. Nutrients 10: 1357. https://doi.org/10.3390/nu10101357

Vercruysse, L., Smagghe, G., Herregods, G. and Van Camp, J., 2005. ACE inhibitory activity in enzymatic hydrolysates of insect protein. Journal of Agricultural and Food Chemistry 53: 5207-5211.

Verhoeckx, K.C.M., Van Broekhoven, S., Den Hartog-Jager, C.F., Gaspari, M., De Jong, G.A.H., Wichers, H.J., Van Hoffen, E., Houben, G.F. and Knulst, A.C., 2014. House dust mite (Der p 10) and crustacean allergic patients may react to food containing yellow mealworm proteins. Food and Chemical Toxicology 65: 364-373.

Verkerk, M.C., Tramper, J., Van Trijp, J.C.M. and Martens, D.E., 2007. Insect cells for human food. Biotechnology Advances 25: 198-202.

Wathne, A.M., Devle, H., Naess-Andresen, C.F. and Ekeberg, D., 2018. Identification and quantification of fatty acids in T. viridissima, $C$. biguttulus, and C. brunneus by GC-MS. Journal of Lipids, Article ID: 3679247. https://doi.org/10.1155/2018/3679247

Williams, J.P., Williams, J.R., Kirabo, A., Chester, D. and Peterson, M., 2016. Nutrient content and health benefits of insects. In: Dossey, A.T., Morales-Ramos, J.A. and Rojas, M.G. (eds.) Insects as sustainable food ingredients. Academic Press, San Diego, CA, USA, pp. 61-84. 
Womeni, H.M., Linder, M., Tiencheu, B., Mbiapo, F.T., Villeneuve, P., Fanni, J. and Parmentier, M., 2009. Oils of insects and larvae consumed in Africa: potential sources of polyunsaturated fatty acids. Oilseeds and fats, Crops and Lipids 16: 230-235.

World Food Programme (WFP), 2015. Hunger statistics. Fighting hunger worldwide. World Food Programme, Rome, Italy. Available at: http://www.wfp.org/hunger/stats

World Health Organisation (WHO), 2020. Obesity and overweight. WHO, Geneva, Switzerland. Available at: https://www.who.int/ news-room/fact-sheets/detail/obesity-and-overweight

Wu, Q., Jia, J., Yan, H., Du, J. and Gui, Z., 2015. A novel angiotensin-I converting enzyme (ACE) inhibitory peptide from gastrointestinal protease hydrolysate of silkworm pupa (Bombyx mori) protein: biochemical characterization and molecular docking study. Peptides 68: 17-24.

Yates-Doerr, E., 2014. The world in a box? Food security, edible insects, and 'One World, One Health' collaboration. Social Science \& Medicine 129: 106-112. https://doi.org/10.1016/j. socscimed.2014.06.020

Yi, L., Lakemond, C.M.M., Sagis, L.M.C., Eisner-Schadler, V., Van Huis, A. and Van Boekel, M.A.J.S., 2013. Extraction and characterisation of protein fractions from five insect species. Food Chemistry 141: 3341-3348.

Ylla, G., Nakamura, T., Itoh, T., Kajitani, R., Toyoda, A., Tomonari, S., Bando, T., Ishimaru, Y., Watanabe, T., Fuketa, M., Matsuoka, Y., Noji, S., Mito, T. and Extavour, C.G., 2020. Cricket genomes: the genomes of future food. bioRxiv, https://doi.org/10.1101/2020.07.07.191841
Young, W., Arojju, S.K., McNeill, M.R., Rettedal, E., Gathercole, J., Bell, N. and Payne, P., 2020. Feeding bugs to bugs: edible insects modify the human gut microbiome in an in vitro fermentation model. Frontiers in Microbiology Frontiers 11: 1763. https://doi. org/10.3389/fmicb.2020.01763

Zacour, A.C., Silva, M.E., Cecon, P.R., Bambirra, E.A. and Vieira, E.C., 1992. Effect of dietary chitin on cholesterol absorption and metabolism in rats. Journal of Nutritional Science and Vitaminology 38: 609-613.

Zhang, Y., Wang, N., Wang, W., Wang, J., Zhu, Z. and Li, X., 2016. Molecular mechanisms of novel peptides from silkworm pupae that inhibit $\alpha$-glucosidase. Peptides 76: 45-50.

Zheng, J., Yuan, X., Cheng, G., Jiao, S., Feng, C., Zhao, X., Yin, H., $\mathrm{Du}, \mathrm{Y}$. and Liu, H., 2018. Chitosan oligosaccharides improve the disturbance in glucose metabolism and reverse the dysbiosis of gut microbiota in diabetic mice. Carbohydrate Polymers 190: 77-86.

Zhou, J. and Han, D., 2006. Safety evaluation of protein of silkworm (Antheraea pernyi) pupae. Food and Chemical Toxicology 44: 11231130.

Zielińska, E., Baraniak, B. and Karaś, M., 2017a. Antioxidant and anti-inflammatory activities of hydrolysates and peptide fractions obtained by enzymatic hydrolysis of selected heat-treated edible insects. Nutrients 9: 970. https://doi.org/10.3390/nu9090970

Zielińska, E., Karaś, M. and Jakubczyk, A., 2017b. Antioxidant activity of predigested protein obtained from a range of farmed edible insects. International Journal of Food Science \& Technology 52: 306-312.

Zielinska, E., Karas, M., Baroniak, B. and Jakubczyk, A., 2020. Evaluation of ACE, alpha-glucosidase, and lipase inhibitory activities of peptides obtained by in vitro digestion of selected species of edible insects. European Food Research and Technology 246: 1361-1369.

\section{Appendix A}

\section{Example primary search syntax used in SCOPUS}

TITLE-ABS-KEY ('edible insects' OR 'entomophagy' OR 'edible insect' OR 'minilivestock' OR 'microlivestock' OR 'minilivestock' OR 'micro-livestock' OR 'farmed insect' OR 'insect cultivation' OR 'insect farming' OR 'insect agriculture' OR 'insect protein' OR 'insect oil' OR 'insect fat' OR 'insect protein isolate' OR 'insect meal' OR 'insect powder') AND TITLEABS-KEY ('human trial' OR 'intervention' OR 'clinical trial' OR 'crossover' OR 'health study' OR 'dietary' OR 'dietary intervention' OR 'feeding study' OR 'case study' OR 'epidemiological study' OR 'supplementation' OR 'experimental group' OR 'experiment' OR 'trial' OR 'case control' OR 'case-control' OR 'case study') 
